\title{
Distal Bile Duct Cancer pT4 TNM Finding v8
}

National Cancer Institute

\section{Source}

National Cancer Institute. Distal Bile Duct CancerpT4 TNM Finding v8. NCI Thesaurus.

Code $C 134803$.

Distal bile duct cancer with tumor involving the celiac axis, superior mesenteric artery, and/or common hepatic artery. (from AJCC 8th Ed.) 